DOI: 10.15587/2706-5448.2021.230777

Article type «Reports on Research Projects»

\section{Julia Yereshko, Iryna Kreidych}

\title{
INTELLECTUAL THEORY OF VALUE: SUBSTANTIATION AND FORMULATION
}

The object of research is the role of the intellectual capital and knowledge in modern economics and value creation process. Therefore, taking into account the intellectual component of value due to the transformation of the society's productive forces structure in the transition to a post-industrial economic system, there was proven the necessity of rethinking the existing theories of value.

Based on the classic politeconomists, neoclassics and institutionalists groundwork analysis, there was defined the economic essence of the intellectual capital. This essence consisted in the people's capacity, using the personal factor of production, rather part of it - the knowledge and intellect, to produce objectified factors. Also, there was justified the place of an intellectual capital in a system of productive forces - its feature of simultaneous affiliation to an immaterial (as a form of individual development), as far as to a material (applied knowledge) spheres.

Due to active modern automation and robotics in manufacturing, labour as a factor of production is gradually replaced by knowledge: personal and ones materialized in the means of production. Thus, there are grounds for the assumption that namely knowledge, not labour, that is present in all spheres of social production, but rather, more accurately, the productive part of knowledge - an intellectual capital is the source of the value of goods in a post-industrial (neoindustrial) economic system. Modern economy has inherent significant share the intellectual component that participates in generating the innovative goods as the new value.

Therefore, based on the above stated, the «intellectual theory of value» was formulated, which defines directions for the intellectual economics paradigm development in future.

Keywords: intellectual capital, theories of value, surplus value, intellectual economy, sustainable development, intellectual theory of value.

\section{Introduction}

In the conditions of transitivity of the World economy, namely: its transition to a post-industrial society and related qualitative changes in the conditions of economic activity, covering all spheres and sectors of social production, the structure of productive forces is being transformed. Innovation and intellectual components, herewith, play a crucial role in the transformation of the World economic system, as consequently evidenced by the actualization of the «intellectual economy» theory - an economic system where knowledge is a key factor in the development of tangible and intangible production.

In the 21st century, the proliferation of economic studies and research concerning the knowledge economy, human and intellectual capital, etc., is being particularly active in response to the «value phenomenon of innovative products» - a dollar invested in research and development is eight times more profitable than a dollar invested in physical capital [1-3].
Therefore, the fundamental restructuring of the manufacturing sector of the developed World economies, the constant increase in the share of innovative products in GDP (for the developed countries this indicator was more than $40 \%$ in 2018 [4]). And hence the alternation of the economic structure of value, give reason to believe that, knowledge acquires, if not basic, then, positively, a prominent place in the system of production factors.

Thus, obvious is the need to formulate a new theory of value, which will take into account the intellectual component of the latter.

The first attempts to study knowledge as a source of value were made in [5] with substantiation of the theory of «value created by knowledge». According to author of [5], «we are entering a new state of civilization in which the driving force is the value created by knowledge».

Thus, modern economy is characterized by a significant proportion of the intellectual component involved in the generation of innovative products as a new value. Therefore the object of research is the role of the intellectual 
capital and knowledge in modern economics and value creation process. The aim of the research are the scientific substantiation of the role and place of intellectual capital in the system of productive forces of society as the commodity value dominant and the formulation of the «intellectual theory of value», based on the assumption that that knowledge, not labour, is the source of surplus value.

\section{Methods of research}

The research was carried out using a range of scientific methods, in particular:

- method of analysis in the study of the genesis of value theories;

- methods of studying the causality of phenomena, dialectical synthesis and scientific abstraction when substantiating the economic essence of intellectual capital as a factor of production;

- hypothetical-deductive method in substantiating the intellectual theory of value.

\section{Research results and discussion}

3.1. Understanding the economic essence of an intellectual capital. In order to understand the economic essence of intellectual capital and its role in creating the value of a commodity, it is necessary to explore its place in the system of productive forces of society. Back in the days of the physiocrats, scholars identified two main factors of production - land and labour. During the evolution of economic doctrines and the subject of economic theory, the concept of productive forces evolves as well. For example, further distinguishes capital, land and labour, adds entrepreneurial skills, and using the term «knowledge economy» for the first time in history, grants knowledge the importance of the main and decisive factor of social production and economic growth [6].

In addition, science and knowledge occupy a particular place in the structure of production: as a form of development of the individual and its social consciousness - belong to the immaterial sphere, but as a productive force (applied knowledge) - to the material one. In the process of labour, a person transforms the surrounding environment to their advantage, simultaneously transforming their own inner nature, accumulating knowledge and skills that generates social development as a result. At the same time, the means of production as the materialized factor of social production remain as the revolutionary element of the productive forces and are rapidly changing and evolving with the development of man. It is the evolution of the means of production that represents innovations, which have become the «materialized knowledge». It is the ability of a person, using their personal factor of production, or rather its part - knowledge and intelligence, to generate materialized - innovation, is the intellectual capital [7].

Modern science opens up more and more opportunities for a man to conquer the world, and the acceleration of scientific and technological development can significantly reduce the lag between the development of living and embodied knowledge. Today we are witnessing the intersection of the waves of the scientific and technological revolution, manifested in the active transition to a new character of social and economic reproduction. The dominant feature of the latest scientific and technological development, is videlicet the intellectual capital. It is its dual nature - the combination of personal and materialized components, and the ability to generate innovations that become decisive in the new economy, and active investment in it is the result of the development of science and technology acceleration [8].

The main function entrusted by its owners to intellectual capital is to ensure the sustainable ability to create a surplus product. This ability manifests itself both in the enhancing role of intangible components of production (science intensity of high-tech production), and in, partly active, dependence of sales volumes of a «simple» product on the intellectual component: image, brands, reputation, competence of employees, PR and the like. Thus, apart from the unconditional influence of technical and technological innovations on the cost reduction and the increase of a labour productivity, the role of intellectual capital is manifested in the direct impact on pricing policies and the competitiveness of the company and its products. The brand's popularity and/or reputation of the company today play a key role in shaping the consumer behaviour of most of society, as evidenced by the proliferation of «brand wars» as the main focus of competitive policy on the market. This is due to the fact that the popularity of the brand provides a relatively high demand for the goods/services of the company, and accordingly an acceleration of capital turnover and, consequently, an increase in profitability. Moreover, from the profitability point of view: it is common knowledge that the price of branded goods on average exceeds the price of a similar «no-name» product by $20-200 \%$, for some brands the price difference can be measured by dozens of times. The competence of employees is worth mentioning as well, as it plays an important role in the results of sales of both branded and «simple» goods: the more competent are the workers involved with the sale of the company's products, the greater its volumes are (all other things being equal) [7].

Consequently, it can be concluded that intellectual capital is the dominant source of the value of modern science-intensive type of production, the source of the surplus value of innovative products, as well as the most of goods and services, the realization of which takes place with its use.

3.2. Existing approaches to determining the value. Understanding the category of «value» has been worrying humanity for a long time, since the first formulation of the laws of the exchange of human labour products by Aristotle. The genesis of the theories of the value of goods occurs against the background of the productive factors concepts evolution, which is explained by the stable interrelation of the development of productive forces and the corresponding reassessment of the value structure by economists. At the same time, the allocation of yet another «new» value factor may be associated not so much with the revolutionary changes in the factors of production, but rather with rethinking the role of specific factors in creating the value. For example: the replacement of W. Petty's «Labor Theory of Value» with the J. B. Say's «tri-factorial» model occurs due to qualitative changes in the understanding the nature of value, not to a change in the production factors structure. 
The transition from one theory of value to another is characterized by an effort of a person to comprehend all elementary parts of value and, nevertheless, not a single theory, taken separately, describes them altogether.

Thus, the labour theory of value, formulated by W. Petty, modified by A. Smith, D. Ricardo and other representatives of the Classical School, lacked an understanding of the dual nature of labour, justified later by Marx. Contrary, completed by K. Marx, the classical labour theory of value does not take into account a number of factors and the subjective components of value.

The next attempt to rethink the value of the goods by the economists of the «new wave» is based on the three-factor model of social production introduced by J. B. Say and the idea that the market is the source for establishing the value of a commodity, because before entering the market, the value of each item appears to be abstract [9]. Here, the value of the goods is created by three factors: capital, land and labour, and the contribution of each factor in the value determines the market. For the first time, Say substantiates the utility of a product as a value factor, but his given idea does not receive a specific analytical statement.

Contrary, though rather logically consistent, the marginal theory of value becomes a cornerstone in the approach to interpret the category «value». The ideas of marginalists are reduced to the marginal utility as the determining factor in the value of goods, stressing the inexpediency and failure of cost theories in terms of the assessment of consumer behaviour of economic agents.

The synthetic theory of A. Marshall, based on the dialectical conjunction of Marxian and marginal concepts, becomes revolutionary in terms of maximizing the comprehension of the totality of elementary factors of value, by distinguishing the «antagonistic» elements of value: objective (capital expenditure) and subjective (consumer behaviour) as components of the mechanism of interaction of supply and demand. This theory received a logical continuation with the formulation of the Walras's General Equilibrium Model.

3.3. Modern theory of value. The modern stage of the development of productive forces in the process of transforming post-industrial changes, the introduction of «new combinations of resource use» [10] prompts another rethinking of the value structure based on the new, innovative nature of the development of society and economy.

The evolutionary contradiction of the aforementioned theories, in our opinion is questionable, because the development of views on the factors and the structure of value takes place in a dialectical unity and, consequently, in a logical sequence. In the end, this very cognition sequence of the economic essence of the category «commodity value» gives us reason to assert the absence, or rather, not exploration of such a key element in the structure of value as knowledge.

The author of [11] writes, that: «All goods can be reduced to labour, as to what that there is same in them». Such a thesis is more than fair to the level of social and economic development at the time of Marx, however, today labour as a factor of production is gradually disappearing in some spheres and branches of the economy as a result of active automation and robotizing of production. However, a person as a factor of production remains in the form of knowledge, their personal knowledge and ones materialized in other productive factors.

Therefore, one can express the hypothesis that today such a unifying factor for all goods (works, services) is knowledge - an intellectual component of value, since it is in fact knowledge, unlike labour, that is present in all spheres and branches of social production, regardless of the level of development of specific means of production.

Consequently, it is knowledge, or rather, the productive part of knowledge in the form of intellectual capital, that is the source of the value of a commodity in a postindustrial (neo-industrial) economic system. In addition, the intellectual theory of value is not a negation of synthetic, but rather its logical continuation, since the intellectual component is present in both elements of value:

- objective - as a determining factor of scientific and technical development of means of production;

- subjective - influencing consumer behaviour by using image, brands, reputation, competence of employees, public relations and the like.

The multidimensional nature of knowledge and systemic heterogeneity distinguishes them from «traditional» economic factors. So, a part of knowledge can't be separated from their carrier, or can't be copied, others, on the contrary, are actively and freely replicated. Thus, on the one hand, enterprises do not have intellectual capital in its entirety - its part belongs to labour force, buyers, counteragents, intermediaries, etc., on the other hand, taking into account current business tendencies, the factor of exploitation of intellectual capital carriers equals (if not exceeds) the labour exploitation coefficient of the times of Marx's «Theory of surplus value».

The problem of analysing the economic effect of using intellectual capital follows from the problem of its evaluation [12]. Today, however, there is no single approach that can take into account the peculiarities of the economic essence of intellectual capital and its specific dual nature. Thus, the assessment, of course, undergoes a part embodied in the form of innovations, at the same time, the evaluation of a part personal part - the potential for a person to generate knowledge and the potential for transforming this knowledge into innovations, intellectual property, and so on - acquires particular difficulty.

\section{Conclusions}

The study reviled that transformation of the society's productive forces structure in the process of transition to a post-industrial economic system requires a rethinking of the existing theories of the value of goods in the context of the consideration of its intellectual component. Under a modern active automation and robotic production, labour as a factor of production is gradually replaced by knowledge, personalized and materialized in the means of production.

Thus, there are grounds to assume, that it is knowledge, not labour, that is present in all spheres of social production, or rather, the productive part of knowledge in the form of intellectual capital is a source of value for goods in a post-industrial (neo-industrial) economic system. Simultaneously, intellectual theory of value substantiated here logically evolves from the Synthetic, given the fact that the intellectual component is present in both elements of value: objective and subjective. 
The scientific novelty of the research is the theoretical formulation of the «intellectual theory of the value of goods», as well as the definition of directions for the concept of intellectual economics paradigm development.

\section{References}

1. Mikhneva, S. G. (2003). Intellektualizatsiya ekonomiki: innovatsionnoe proizvodstvo i chelovecheskiy kapital. Innovatsii, $1,49-54$.

2. Iacuzzi, S., Massaro, M., Garlatti, A. (2020). Value creation through collective intelligence: Managing intellectual capital. The Electronic Journal of Knowledge Management, 18 (1), 68-79.

3. Nielsen, C., Dane-Nielsen, H. (2019). Value creation in business models is based on intellectual capital - And only intellectual capital!. Journal of Business Models, 7 (2), 64-81.

4. Sakaiya, T. (1991). The Knowledge-Value Revolution or a History of the Future. Kodansha USA Inc., 379.

5. Global Innovation Index: Annual Report 2018. Available at: https://www.globalinnovationindex.org/gii-2018-report

6. Fedulova, L. I. (2009). Ekonomika znan. Kyiv: NAN Ukrainy, 600.

7. Yereshko, Yu. O. (2016). Economic essence of an intellectual capital as the economy's innovative development factor. Ekonomichnyi visnyk Natsionalnoho tekhnichnoho universytetu Ukrainy «Kyivskyi politekhnichnyi instytut», 13. doi: http:// doi.org/10.20535/2307-5651.13.2016.80080
8. Yalovyi, H. K., Yereshko, Yu. O. (2015). The methodology of scientific and technical development in a post-industrial society concept. Ekonomichnyi visnyk Natsionalnoho tekhnichnoho universytetu Ukrainy Kyizskyi politekhnichnyi instytut, 12, 71-82.

9. Bazylevych, V. D., Hrazhevska, N. I., Haidai, T. V., Leonenko, P. M., Nesterenko, A. P. (2004). Istoriia ekonomichnykh uchen. Kyiv: Znannia, 1300.

10. Schumpeter, J. (1934). The Theory of Economic Development. Harvard Economic Studies, 255.

11. Marks, K., Engels, F. (1968). Kritika politicheskoy ekonomii. Soch, 46 (I), 256-301.

12. Caddy, I. (2002). Issues concerning intellectual capital metrics and measurement of intellectual capital. Singapore Management Reviеге, 24 (3), 77-90.

Julia Yereshko, PhD, Associate Professor, Department of Theoretical and Applied Economics, National Technical University of Ukraine «Igor Sikorsky Kyiv Polytechnic Institute», Kyiv, Ukraine, e-mail: julia.jereshko@gmail.com, ORCID: https://orcid.org/00000002-9161-8820

Iryna Kreidych, Doctor of Economic Sciences, Professor, Head of Department of Theoretical and Applied Economics, National Technical University of Ukraine «Igor Sikorsky Kyiv Polytechnic Institute», Kyiv, Ukraine, e-mail:kreidichin@gmail.com, ORCID: https:// orcid.org/0000-0002-4594-2160 